\title{
Association of Leptin with Total and Free Testosterone: Results from the National Health and Nutrition Examination Surveys
}

\author{
Thiago Fernandes Negris Lima, ${ }^{1, *, \dagger}$ Sirpi Nackeeran, ${ }^{1, \dagger}$ Evgeniya Rakitina, ${ }^{1}$ Gustavo Fernandes Negris Lima, ${ }^{2}$ \\ Himanshu Arora, ${ }^{1,3,4}$ Atil Y. Kargi, ${ }^{3,5}$ and Ranjith Ramasamy ${ }^{1,3}$
}

\begin{abstract}
Introduction: Obese men can have testosterone deficiency (TD) but the etiology is uncertain. Leptin is a 16-kDa protein produced primarily by adipose tissue and, therefore, is positively associated with the amount of body fat and can affect testosterone (T) production. We hypothesized that increased leptin can be independently associated with low T.

Materials and Methods: We performed a cross-sectional analysis of men from National Health and Nutrition Examination III database to evaluate the association of leptin with serum $\mathrm{T}$ and calculated free testosterone (CFT). Linear regression was performed with leptin, age, waist circumference, hypertension, and diabetes as independent variables predicting $\mathrm{CFT} / \mathrm{T}$. Multiple linear regression was used to determine predictors for $\mathrm{CFT}$ and $T$ using variables previously significant in the univariate analysis.

Results: A total of 1193 men were analyzed. As expected, older and obese men were associated with having lower T. Interestingly, increasing leptin levels were an independent predictor of decreasing T and cFT on multivariable analysis. Increasing $1 \mathrm{ng} / \mathrm{mL}$ in leptin resulted in a decrease of 5.13 and $0.11 \mathrm{ng} / \mathrm{dL}$ of $T$ and cFT, respectively ( $p<0.05$ ). Also, every additional year of life led to a T and cFT reduction of 2.87 and $0.13 \mathrm{ng} / \mathrm{dL}$, respectively, and increasing $1 \mathrm{~cm}$ in waist circumference corresponded to decrease of $4 \mathrm{ng} / \mathrm{dL}$ in $\mathrm{T}(p<0.05)$.

Conclusions: We concluded that increasing leptin, age, and waist circumference were associated with decreasing of T and CFT. Elevated leptin levels could be one of the potential etiologies of TD.
\end{abstract}

Keywords: leptin; testosterone; NHANES; obesity; free testosterone

\section{Introduction}

Worldwide obesity has tripled since 1975 . According to the World Health Organization, in 2016, 1.9 billion (39\%) of adults were overweight. Of these $>650$ million (13\%) were obese. ${ }^{1}$ Recent clinical evidence suggests that obesity is one of the most important risk factors for secondary hypogonadism in men. ${ }^{2}$
Many mechanisms have been suggested to cause low total testosterone $(\mathrm{T})$ in male obese patients including lower sex hormone binding globulin (SHBG) levels due to a suppression of hepatic SHBG synthesis by elevated concentrations of insulin (in vitro study with Hep G2 cells), ${ }^{3}$ reduced SHBG caused by the elevated concentration of lipid in the liver, and by high content

\footnotetext{
${ }^{1}$ Department of Urology, University of Miami Miller School of Medicine, Miami, Florida, USA.

${ }^{2}$ Mechanical Engineering, Federal University of Espirito Santo (UFES), Vitoria, Brazil.

${ }^{3}$ The Interdisciplinary Stem Cell Institute, Miller School of Medicine, University of Miami, Miami, Florida, USA.

${ }^{4}$ Department of Human Genetics, John P Hussman Institute for Human Genomics, Miller School of Medicine, University of Miami, Miami, Florida, USA

${ }^{5}$ Division of Endocrinology, Department of Medicine, University of Miami Miller School of Medicine, Miami, Florida, USA.

'Authors contributed equally.
}

*Address correspondence to: Thiago Fernandes Negris Lima, MD, Department of Urology, University of Miami Miller School of Medicine, Clinical Research Building (CRB), 1120 NW 14th Street Suite 1551C, Miami, FL 33136, USA, E-mail: thiagofernandesnl@gmail.com

(C) Thiago Fernandes Negris Lima et al., 2020; Published by Mary Ann Liebert, Inc. This Open Access article is distributed under the terms of the Creative Commons License (http://creativecommons.org/licenses/by/4.0), which permits unrestricted use, distribution, and reproduction in any medium, provided the original work is properly cited. 
of proinflammatory cytokines, ${ }^{4}$ elevated peripheral conversion of $\mathrm{T}$ to estradiol $\left(\mathrm{E}_{2}\right)$, and its negative feedback to the hypothalamic-pituitary-gonadal (HPG) axis, ${ }^{5}$ and direct and indirect effects of leptin on the HPG axis. ${ }^{6}$

Leptin is a 167 amino acid peptide, product of the $o b$ gene, mainly produced in white adipose tissue. It regulates energy balance by optimizing energy expenditure, inhibiting food intake, and it is strongly correlated (positive) with the amount of body fat. ${ }^{7}$ Thus, weight loss is associated with reduction of leptin levels. ${ }^{8}$ Leptin has not only been associated with regulation of body fat stores but also has clear regulatory functions within the HPG axis. ${ }^{9}$

In a state of decreased energy supply, a decreased leptin level has been found to be a key mediator of neuroendocrine abnormalities seen in hypogonadotropic hypogonadism. ${ }^{6,10}$ In contrast, high-fat diet-induced obesity resulted in elevation of leptin and downregulation of kisspeptins and gonadotropin-releasing hormone $(\mathrm{GnRH})$ secretion in the hypothalamus of mice and humans, ${ }^{11}$ possibly contributing to male hypogonadotropic hypogonadism. ${ }^{12}$ Interestingly, Leydig cells have leptin receptors as well. ${ }^{13}$ It has been suggested that high serum levels of leptin could actively impair 17,20 lyase steps of the testicular steroidogenic pathway, causing decreased intratesticular T production. ${ }^{13}$

Several studies suggest that the regulation of testicular steroidogenesis is influenced by leptin among other hormones. ${ }^{6,12-14}$ The gap in knowledge is to understand the underlying etiology for testosterone deficiency (TD) in obese men. We hypothesized that serum leptin would be inversely associated with $\mathrm{T}$ and free testosterone (FT) levels. We examined the National Health and Nutrition Examination Survey (NHANES), assessing demographic characteristics, serum leptin, and T. We have also calculated FT using total T, SHBG, and albumin.

\section{Materials and Methods}

\section{Data source and study population}

This study is a cross-sectional analysis of 1193 men of ages 20-90 years based on the NHANES III database survey from 1988 to 1991 and available online. ${ }^{15}$ The NHANES is a collection of studies designed by the Center for Disease Control and Prevention (CDC) to determine the dietary status and overall health of individuals within the United States. ${ }^{16}$ Only the 1988-1991 data cycle was included, because other data cycles were either missing in T or leptin data. Baseline characteris- tics of age, race, waist circumference, diabetes, hypertension, and smoking status, as well as leptin and T levels, were assessed. Subjects were evaluated according to their waist circumference since it was previously reported to be a better predictor of obesity-related health risk in the NHANES III population. ${ }^{17,18}$

The NHANES collects its data through a complex multistage probability sampling design with testing conducted at several distinct sites. Owing to this methodology, certain subgroups are overrepresented in the NHANES sample. To account for this, the NHANES assigns sample weight, variance, and cluster variables to adjust the sample population to the United States census. All analyses for this study were conducted utilizing these sample weights, variances, and clusters as recommended by the NHANES guidelines.

\section{Ethics statement}

Per the National Center for Health Statistics Ethics Review Board, all participants submitted a written consent to be enrolled in this study (https://www.cdc.gov/ nchs/nhanes/irba98.htm).

\section{Covariables and primary outcome}

Our primary outcome was to determine the association between serum leptin, calculated free testosterone (cFT), and T levels after excluding possible confounders, such as age, history of diabetes, history of hypertension, and waist circumference. Since cigarette smoking was not associated with low $\mathrm{T}$, we excluded it from the analysis. ${ }^{19}$ A competitive electrochemiluminescence immunoassay on the 2010 Elecsys autoanalyzer (Roche Diagnostics, Indianapolis, IN) was used to quantify serum $T, E_{2}$, and SHBG concentrations, which were archived in the NHANES database.

$\mathrm{T}$ results were obtained in $\mathrm{ng} / \mathrm{mL}$ and converted to $\mathrm{ng} / \mathrm{dL}$, since this is the unit used most commonly in

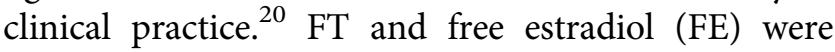
also calculated from SHBG, albumin, and T using the method of Vermeulen et al., ${ }^{21}$ relying on the assumption that the concentration of these fractions is determined mainly by the interaction of albumin, SHBG with total $\mathrm{T}$ or total $\mathrm{E}_{2}{ }^{22}$ Serum leptin concentrations were measured by radioimmunoassay after storage at $-70^{\circ} \mathrm{C}$ for 8 years and after one freeze-thaw cycle on average. ${ }^{23}$ As a secondary outcome, we assessed the association between waist circumference and leptin levels in a multiple regression analysis, to validate our findings with previous studies. ${ }^{5,7,9}$ 


\section{Statistical analysis}

Statistical analysis was performed using $\mathrm{SAS}^{\circledR}$ version 9.4 (SAS Institute, Inc., Cary, NC) and GraphPad Prism version 8 (GraphPad Software, Inc.). All data analyzed were weighted using the appropriate strata and cluster per CDC recommendations. Measures of central tendencies and variability were reported as mean and standard deviation, respectively. $t$-Test was used to compare continuous variables and chi-squared test was used to compare categorical variables.

We performed univariate linear regression analysis using leptin, $\mathrm{E}_{2}$, age, waist circumference, hypertension, and diabetes to determine which variables would have an effect on cFT and T levels. Subsequently, a multiple linear regression was used to determine the best predictors for $\mathrm{cFT}$ and $\mathrm{T}$, controlling for all confounding variables that were significant in the univariate analysis. Participants were included regardless of smoking status. We also performed a multiple linear regression analysis including age, $\mathrm{T}$, waist circumference, diabetes, and hypertension to predict leptin levels.

To avoid multicollinearity, we confirmed that none of the analysis variables had a high degree of correlation through calculation of tolerance for each independent variable. In addition, we calculated the influence of data points through the Cook's distance of each case and the Durbin-Watson test was performed to assess autocorrelation of the residuals in each model. The significance level was set at $p<0.05$.

\section{Results}

A total of 1193 men $>20$ years of age had baseline characteristics, leptin, and $\mathrm{T}$ levels for the analysis. The clinical and demographic information is given in Table 1. As expected from a population sample, most men had normal T, $542.6 \mathrm{ng} / \mathrm{dL}$ ( $95 \%$ confidence interval 524.9-560.35). The prevalence of men with $\mathrm{T}<300 \mathrm{ng} / \mathrm{dL}$ was $8.9 \%$ (106 men). In addition, the prevalence of diabetes and hypertension in this population was $3 \%$ and $19 \%$, respectively.

In the simple linear regression analysis, most variables (leptin, age, waist circumference, hypertension, and diabetes) were negatively associated with variation in $\mathrm{T} \mathrm{lev-}$ els $(p<0.05)$, whereas $\mathrm{E}_{2}$ was only positively associated with T levels $\left(R^{2}=0.13, p=0.0011\right)$. When evaluating predictors for cFT, we observed a similar pattern, where leptin, age, waist circumference, hypertension, and diabetes negatively predicted cFT levels $(p<0.05)$; $\mathrm{E}_{2}$ positively predicted cFT levels $\left(R^{2}=0.16, p=0.0006\right)$.
Table 1. Baseline Characteristics of Participants

\section{Meeting Inclusion Criteria}

\begin{tabular}{|c|c|}
\hline Variables & Mean $(95 \% \mathrm{Cl})$ \\
\hline \multicolumn{2}{|l|}{ Gender $^{\mathrm{a}}$} \\
\hline Men (\%) & $100(100-100)$ \\
\hline Women (\%) & $0(0-0)$ \\
\hline Age $(\text { years })^{\mathrm{b}}$ & $42.1(40.6-43.6)$ \\
\hline Testosterone $(\mathrm{ng} / \mathrm{dL})^{\mathrm{b}}$ & $542.6(524.9-560.35)$ \\
\hline Free testosterone $(\mathrm{ng} / \mathrm{dL})^{\mathrm{b}, \mathrm{c}}$ & $11.0(10.6-11.4)$ \\
\hline Leptin $(\mathrm{ng} / \mathrm{mL})^{\mathrm{b}}$ & $5.8(5.3-6.4)$ \\
\hline Sex hormone binding globulin $(\mathrm{nmol} / \mathrm{L})^{\mathrm{b}}$ & $37.7(36.2-39.2)$ \\
\hline Estradiol $(\mathrm{pq} / \mathrm{mL})^{\mathrm{b}}$ & $37.5(36.0-39.0)$ \\
\hline Free estradiol $(\mathrm{pg} / \mathrm{mL})^{\mathrm{b}}$ & $0.64(0.62-0.67)$ \\
\hline Waist circumference $(\mathrm{cm})^{\mathrm{b}}$ & $94.7(93.3-96.0)$ \\
\hline \multicolumn{2}{|l|}{ BMI categories $\left(\mathrm{kg} / \mathrm{m}^{2}\right)^{\mathrm{a}}$} \\
\hline$<25(\%)$ & $44.1(40.6-47.7)$ \\
\hline $25-29.9(\%)$ & $37.6(33.7-41.5)$ \\
\hline $30-34.9(\%)$ & $13.4(10.6-16.2)$ \\
\hline$\geq 35(\%)$ & $4.9(2.8-6.9)$ \\
\hline \multicolumn{2}{|l|}{ Diabetes $^{\mathrm{a}}$} \\
\hline No $(\%)$ & $97.0(95.9-98.1)$ \\
\hline Yes (\%) & $3.0(1.9-4.1)$ \\
\hline \multicolumn{2}{|l|}{ Hypertension $^{\mathrm{a}}$} \\
\hline No $(\%)$ & $81.0(78.4-83.5)$ \\
\hline Yes (\%) & $19.0(16.5-21.6)$ \\
\hline \multicolumn{2}{|l|}{ Race $^{a}$} \\
\hline Black (\%) & $9.7(6.8-12.5)$ \\
\hline Mexican (\%) & $4.8(2.9-6.8)$ \\
\hline White (\%) & $78.4(72.0-84.8)$ \\
\hline Other (\%) & $7.1(2.7-11.5)$ \\
\hline \multicolumn{2}{|l|}{ Testosterone $<300 \mathrm{ng} / \mathrm{dL}^{\mathrm{a}, \mathrm{d}}$} \\
\hline No $(\%)$ & $91.1(89.0-93.3)$ \\
\hline Yes (\%) & $8.9(6.7-11.0)$ \\
\hline
\end{tabular}

aPercentages adjusted to account for complex survey design and unweighted numbers.

${ }^{b}$ Mean value of continuous variables in the analysis population with values and confidence limits adjusted to account for complex survey design and unweighted numbers.

'Values calculated according to previously validated methods (Vermeulen).

dPatients included by serum T only as symptoms of clinical hypogonadism were not recorded in the NHANES database.

BMI, body mass index; $\mathrm{Cl}$, confidence interval; NHANES, National Health and Nutrition Examination Survey.

FE was not associated with variation of $\mathrm{T}$ or cFT levels $\left(p>0.05, R^{2}=0.00\right)$ (Table 2).

Including only the significant independent variables from the simple linear analyses, we proceeded with a multiple linear regression analysis to predict $\mathrm{T}$ and cFT levels. The analysis showed that increasing leptin, age, and waist circumference negatively predicted $\mathrm{T}$ levels $(p<0.05)$, and as expected, $\mathrm{E}_{2}$ was a positive predictor $(p=0.0024)$. A similar pattern held true for the predictors of cFT levels, where leptin levels $(p=0.0004)$ and age $(p<0.001)$ showed negative association with $c F T$, whereas $\mathrm{E}_{2}$ showed a positive association $(p=$ $0.0014)$. Our model predicted $38 \%$ and $47 \%$ of the variability of $\mathrm{T}$ and cFT levels, respectively ( $\mathrm{T}^{2}=0.38$, cFT $\left.R^{2}=0.47\right)$. According to our findings, an additional 
Table 2. Simple Linear Regression Investigating Predictors of Total Testosterone and Calculated Free Testosterone

\begin{tabular}{|c|c|c|c|c|c|c|c|c|c|c|c|c|}
\hline \multirow{3}{*}{$\begin{array}{l}\text { Dependent variable } \\
\text { Independent variable }\end{array}$} & \multicolumn{6}{|c|}{ Total testosterone (ng/dL) } & \multicolumn{6}{|c|}{ Calculated free testosterone $(\mathrm{ng} / \mathrm{dL})$} \\
\hline & \multirow[b]{2}{*}{ B } & \multirow[b]{2}{*}{ SE } & \multicolumn{2}{|c|}{$95 \% \mathrm{Cl}$} & \multirow[b]{2}{*}{$p$} & \multirow[b]{2}{*}{$R^{2}$} & \multirow[b]{2}{*}{ B } & \multirow[b]{2}{*}{ SE } & \multicolumn{2}{|c|}{$95 \% \mathrm{Cl}$} & \multirow[b]{2}{*}{$p$} & \multirow[b]{2}{*}{$R^{2}$} \\
\hline & & & Lower & Upper & & & & & Lower & Upper & & \\
\hline Leptin $(\mathrm{ng} / \mathrm{mL})$ & $-12.59^{*}$ & 2.97 & -18.73 & -6.46 & 0.0003 & 0.13 & $-0.19^{*}$ & 0.05 & -0.29 & -0.09 & 0.0005 & 0.06 \\
\hline Estradiol $(\mathrm{pg} / \mathrm{mL})$ & $5.89^{*}$ & 1.59 & 2.61 & 9.17 & 0.0011 & 0.13 & $0.14^{*}$ & 0.04 & 0.07 & 0.22 & 0.0006 & 0.16 \\
\hline Free estradiol $(\mathrm{pg} / \mathrm{mL})$ & -7.44 & 32.55 & -74.79 & 59.90 & 0.8211 & 0.00 & 0.31 & 0.50 & -0.74 & 1.35 & 0.5514 & 0.00 \\
\hline Age (years) & $-4.36^{*}$ & 0.55 & -5.50 & -3.23 & $<0.0001$ & 0.13 & $-0.15^{*}$ & 0.01 & -0.17 & -0.13 & $<0.0001$ & 0.32 \\
\hline Waist circumference $(\mathrm{cm})$ & $-6.38^{*}$ & 0.51 & -7.43 & -5.34 & $<0.0001$ & 0.20 & $-0.10^{*}$ & 0.01 & -0.12 & -0.07 & $<0.0001$ & 0.10 \\
\hline Hypertension (yes vs. no) & $-74.71^{*}$ & 22.50 & -121.25 & -28.17 & 0.0030 & 0.02 & $-1.93^{*}$ & 0.48 & -2.92 & -0.93 & 0.0006 & 0.03 \\
\hline Diabetes (yes vs. no) & $-134.39^{*}$ & 18.15 & -171.93 & -96.85 & $<0.0001$ & 0.01 & -2.92 & 0.41 & -3.78 & -2.06 & $<0.0001$ & 0.01 \\
\hline
\end{tabular}

$1 \mathrm{ng} / \mathrm{mL}$ in leptin levels resulted in a reduction of 5.13 and $0.11 \mathrm{ng} / \mathrm{dL}$ of $\mathrm{T}$ and $\mathrm{cFT}$, respectively $(p<0.05)$. Also, we observed a reduction of $2.87 \mathrm{ng} / \mathrm{dL}$ in $\mathrm{T}$ and $0.13 \mathrm{ng} / \mathrm{dL}$ in $\mathrm{cFT}$ for every additional year of life $(p<0.05)$. Moreover, we perceived a reduction of $4 \mathrm{ng} / \mathrm{dL}$ in $\mathrm{T}$ levels $(p<0.05)$ for every additional $1 \mathrm{~cm}$ in the waist circumference (Table 3 ). Older and obese men were associated with lower levels of T. Interestingly, men with higher leptin levels had lower $\mathrm{T}$, independent of waist circumference and age.

In the multivariate linear model to predict leptin level, waist circumference and age were the only significant variables. For every additional $1 \mathrm{~cm}$ of waist circumference, we observed an increase of $0.27 \mathrm{ng} / \mathrm{mL}$ $(p<0.0001)$. Conversely, the addition of 1 year of age led to a decrease of $0.04 \mathrm{ng} / \mathrm{mL}$ in leptin levels $(p<0.05)$. This model predicted $50 \%$ variability of leptin levels $\left(R^{2}=0.50\right)$ (Table 4$)$.

\section{Discussion}

Besides its proven relationship with body fat, ${ }^{7}$ leptin, in high levels, is believed to inhibit the testicular ste- roidogenic pathway ${ }^{24}$ and downregulate GnRH production and secretion, ${ }^{11,25}$ causing low $\mathrm{T}$ levels in men. This finding could justify the higher incidence of low $\mathrm{T}$ in the obese population when compared with the nonobese. The purpose of this cross-sectional analysis was to evaluate the negative association between serum leptin, FT, and serum T in men. Variables, such as age, leptin, and waist circumference negatively impacted $\mathrm{T}$ levels, giving support to previous studies that suggested that metabolic syndrome and insulin resistance were related to hypogonadism in men. ${ }^{26,27}$ Curiously, only leptin and age were negatively associated with cFT levels.

Previous studies have demonstrated that the regulation of leptin and T levels seems to be bidirectional. ${ }^{28,29}$ Our population level study supports previous findings in smaller sample size studies that establish negative associations between leptin and serum $\mathrm{T}^{28}$ and a positive association between leptin and obesity. ${ }^{7,8}$ The presence of a significant association between leptin and $\mathrm{T}$ independent of waist circumference indicates that elevated leptin levels could lead to TD regardless

Table 3. Multiple Linear Regression Model Predicting Total Testosterone (ng/dL) and Calculated Free Testosterone (ng/dL)

\begin{tabular}{|c|c|c|c|c|c|c|c|c|c|c|}
\hline \multirow[b]{3}{*}{ Variable } & \multicolumn{5}{|c|}{ Total testosterone } & \multicolumn{5}{|c|}{ Calculated free testosterone } \\
\hline & \multirow[b]{2}{*}{$B$} & \multirow[b]{2}{*}{ SE } & \multicolumn{2}{|c|}{$95 \% \mathrm{Cl}$} & \multirow[b]{2}{*}{$p$} & \multirow[b]{2}{*}{$B$} & \multirow[b]{2}{*}{ SE } & \multicolumn{2}{|c|}{$95 \% \mathrm{Cl}$} & \multirow[b]{2}{*}{$p$} \\
\hline & & & Lower & Upper & & & & Lower & Upper & \\
\hline Leptin (ng/mL) & $-5.13^{*}$ & 2.20 & -9.68 & -0.59 & 0.0285 & $-0.11^{*}$ & 0.03 & -0.17 & -0.06 & 0.0004 \\
\hline Estradiol (pg/mL) & $5.38 *$ & 1.58 & 2.12 & 8.64 & 0.0024 & $0.12^{*}$ & 0.03 & 0.05 & 0.20 & 0.0014 \\
\hline Age (years) & $-2.87^{*}$ & 0.43 & -5.61 & -2.39 & $<0.0001$ & $-0.13^{*}$ & 0.01 & -0.15 & -0.11 & $<0.0001$ \\
\hline Waist circumference (cm) & $-4.00^{*}$ & 0.78 & -5.61 & -2.39 & $<0.0001$ & -0.02 & 0.01 & -0.05 & 0.00 & 0.0963 \\
\hline Diabetes (yes vs. no) & -8.40 & 22.59 & -55.13 & 38.32 & 0.7133 & 0.01 & 0.41 & -0.83 & 0.85 & 0.9794 \\
\hline Hypertension (yes vs. no) & 10.62 & 21.86 & -34.59 & 55.83 & 0.6316 & -0.13 & 0.43 & -1.02 & 0.76 & 0.7659 \\
\hline
\end{tabular}

$R^{2} \mathrm{~T}=0.38 ; R^{2} \mathrm{CFT}=0.47$

${ }^{*} p<0.05$.

$\mathrm{T}$, testosterone; $\mathrm{CFT}$, calculated free testosterone. 
Table 4. Multiple Linear Regression Model to Determine Associations with Leptin

\begin{tabular}{|c|c|c|c|c|c|}
\hline \multirow[b]{2}{*}{ Variable } & \multirow[b]{2}{*}{$B$} & \multirow[b]{2}{*}{ SE } & \multicolumn{2}{|c|}{$95 \% \mathrm{Cl}$} & \multirow[b]{2}{*}{$p$} \\
\hline & & & Lower & Upper & \\
\hline Waist circumference $(\mathrm{cm})$ & $0.27^{*}$ & 0.03 & 0.21 & 0.33 & $<0.0001$ \\
\hline Total testosterone $(\mathrm{ng} / \mathrm{mL})$ & -0.25 & 0.14 & -0.53 & 0.03 & 0.0799 \\
\hline Age (years) & $-0.04 *$ & 0.02 & -0.07 & -0.00 & 0.0402 \\
\hline Diabetes (yes vs. no) & -0.40 & 1.31 & -3.10 & 2.31 & 0.7647 \\
\hline Hypertension (yes vs. no) & 0.87 & 0.48 & -0.12 & 1.87 & 0.0821 \\
\hline
\end{tabular}

of body composition. This relationship is further supported by prior studies that revealed leptin's effect on Leydig cell steroidogenesis in murine models. ${ }^{30}$ It is likely that the high leptin levels in obese patients play a role independent of the other factors involved in obesity on comorbid hypoandrogenism. ${ }^{31}$ In contrast, another study suggested that low T could impact leptin levels. ${ }^{32}$ In this study, castrated rats presented with the highest levels of leptin when compared with controls and those receiving exogenous $\mathrm{T}^{33}$ Since the majority of men in this study had normal serum $\mathrm{T}$, low $\mathrm{T}$ was not a predictor of elevated leptin levels (Table 4).

Many studies have associated leptin impact with T production associated with body mass index (BMI). Waist circumference was considered to be a more reliable predictor of obesity-related health risk for the NHANES population, based on Janssen et al. ${ }^{18}$ study assessing waist circumference as a predictor of obesity-related health risk, besides its good association with central obesity and metabolic syndrome. ${ }^{18}$ In addition, in contrast to previous findings, ${ }^{5,27}$ our study showed a positive association between $\mathrm{E}_{2}$ and $\mathrm{T}$ and cFT levels. Since estrogen production in men depends on testicular or peripheral aromatization of androgens, ${ }^{33}$ we expected to see a positive association between $\mathrm{T}$ and $\mathrm{E}_{2}{ }^{34}$

Although obesity is classically a cause of secondary hypogonadism, ${ }^{2,5}$ the frequently elevated concentration of leptin in these individuals appears to directly affect testicular function. To analyze the direct effect of leptin on the testicular function, Isidori et al. ${ }^{35}$ examined the in vivo relationship between leptin levels and sex hormones. In this study, men were subjected to human chorionic gonadotropin (hCG) stimulation (5000 IU) and blood work was monitored for 4 consecutive days. The authors observed that androgen levels were inversely correlated with leptin levels after hCG stimulation. Also, the decreased androgen response to hCG stimulation in obese men was not related to increased aromatase activity and consequent peripheral conversion of $\mathrm{T}$ to $\mathrm{E} 2$, since no significant changes in $\mathrm{E} 2 / \mathrm{T}$ ratio between obese men and lean men were noted. These results suggest that obesity-related TD may not only be related to secondary hypogonadism, but also caused by a deficient testicular response to adequate stimulus. Therefore, leptin appears to have an important role in the regulation of the HPG axis and in the pathogenesis of TD in obese men.

The negative correlation between aging and leptin levels has been previously described. ${ }^{36}$ Leptin levels appear to be reduced in $>50 \%$ in men older than 60 years. ${ }^{37}$ Although in our population, leptin was also negatively associated with age, we observed a less accentuated association, with variation of $0.04 \mathrm{ng} / \mathrm{mL}$ for every year.

Strengths of this study include the very large sample size and the broad range of waist circumference and age, which allows for robust statistical inferences regarding the factors influencing SHBG concentrations. Given the subject pool of NHANES III and its validated weighting methods, this study possibly provided a representative sample of the American population.

Limitations of this study include its retrospective and cross-sectional design. Although our findings of predictors of $\mathrm{T}$ and cFT levels were statistically significant, they yielded predictions that should not be used in clinical practice independently. We understand that these findings can be justified by a multifactorial etiology of hypogonadism that includes genetic conditions, anatomic abnormalities, infection, tumor, medication, comorbidity, and injury. ${ }^{38}$ Furthermore, the lack of data regarding symptoms of hypogonadism in the NHANES database prevented us from analyzing a diagnosis of hypogonadism as an outcome in this study. In addition, our assessment of FT was calculated based on the T and SHBG concentrations as measured with an immunoassay, rather than the gold standard of equilibrium dialysis for the measurement of FT. In contrast, the cFT used in our analyses has been shown to correlate highly with FT measured by equilibrium dialysis and represents a practical measure that is used clinically. ${ }^{21}$

Another limitation was that we did not have access to the list of symptoms, medications, and medical history for each patient. Also, key analysis variables were only available for the NHANES data set from 1988 to 1991 for men aged 20 years and older, which may not reflect the exact demographic characteristics of 
the 2020 male population. In contrast, since obesity prevalence has only increased from the data collection period to the present time, we expect a crescent impact of leptin on $\mathrm{T}$ production.

Previous studies showed that FT was especially affected in the severe obese male population (BMI $\left.>35-40 \mathrm{~kg} / \mathrm{m}^{2}\right) .{ }^{4}$ Since only a small percentage of men in our study had BMI $>35 \mathrm{~kg} / \mathrm{m}^{2}$, we could not replicate this association in the study (Table 1). Our study was additionally limited by the lack of luteinizing hormone data in the NHANES database, which could have served to understand whether the effect of leptin is primarily at the level of the testis or secondarily at the hypothalamus/pituitary gland. Therefore, our conclusions apply only to the measurement of low $\mathrm{T}$ and cFT and not to the diagnosis of hypogonadism, besides having the limitation of not including all possible predictor variables.

\section{Conclusions}

In a large sample representative of the American population, increasing serum leptin is independently associated with both decreasing total and FT levels, even when controlling for other associated factors. Leptin is one of the several factors that can explain the underlying association between obesity and TD.

\section{Authors' Contributions}

Conception of the study was done by T.F.N.L., S.N., H.A., and R.R. Data acquisition was carried out by E.R. and S.N. Data analysis was carried out by E.R., S.N., and T.F.N.L., G.F.N.L. Interpretation of data was performed by T.F.N.L., E.R., S.N., G.F.N.L., H.A., A.Y.K., and R.R. Writing - original draft-of the article was by T.F.N.L., E.R., S.N., H.A., A.Y.K., and R.R. Writing-review and editing-of the article was by T.F.N.L., S.N., H.A., A.Y.K., and R.R.

\section{Author Disclosure Statement}

No competing financial interests exist.

\section{Funding Information}

No funding was received for this article.

\section{References}

1. World Health Organization. (2018). Obesity and overweight, 2018. www .who.int/news-room/fact-sheets/detail/obesity-and-overweight (accessed March 10, 2020).
2. Saboor Aftab SA, Kumar S, Barber TM. The role of obesity and type 2 diabetes mellitus in the development of male obesity-associated secondary hypogonadism. Clin Endocrinol (Oxf). 2013;78(3):330-337.

3. Plymate SR, Jones RE, Matej LA, Friedl KE. Regulation of sex hormone binding globulin (SHBG) production in Hep G2 cells by insulin. Steroids. 1988;52(4):339-340.

4. Goldman AL, Bhasin S, Wu FCW, Krishna M, Matsumoto AM, Jasuja R. A reappraisal of testosterone's binding in circulation: Physiological and clinical implications. Endocr Rev. 2017;38(4):302-324.

5. Fui MN, Dupuis $P$, Grossmann M. Lowered testosterone in male obesity: Mechanisms, morbidity and management. Asian J Androl. 2014;16(2): 223-231.

6. Chou SH, Mantzoros C. 20 years of leptin: Role of leptin in human reproductive disorders. J Endocrinol. 2014;223(1):T49-T62.

7. Wasim M, Awan FR, Najam SS, Khan AR, Khan HN. Role of leptin deficiency, inefficiency, and leptin receptors in obesity. Biochem Genet. 2016; 54(5):565-572.

8. Nicklas BJ, Katzel LI, Ryan AS, Dennis KE, Goldberg AP. Gender differences in the response of plasma leptin concentrations to weight loss in obese older individuals. Obes Res. 1997;5(1):62-68.

9. Farooq $\mathrm{R}$, Ullah $\mathrm{SL}$, Ishaq $\mathrm{H}$. Relation of serum leptin with sex hormones of obese infertile men and women. J Appl Pharm Sci. 2013; 3(01):60-65.

10. Sanchez-Garrido MA, Tena-Sempere M. Metabolic control of puberty: Roles of leptin and kisspeptins. Horm Behav. 2013;64(2):187-194.

11. Hestiantoro A, Astuti BPK, Muharam R, Pratama G, Witjaksono F, Wiweko B. Dysregulation of kisspeptin and leptin, as anorexigenic agents, plays role in the development of obesity in postmenopausal women. Int J Endocrinol. 2019;2019:1347208.

12. Zhai L, Zhao J, Zhu Y, et al. Downregulation of leptin receptor and kisspeptin/GPR54 in the murine hypothalamus contributes to male hypogonadism caused by high-fat diet-induced obesity. Endocrine. 2018 ; 62(1):195-206.

13. Caprio M, Isidori AM, Carta AR, Moretti C, Dufau ML, Fabbri A. Expression of functional leptin receptors in rodent Leydig cells. Endocrinology. 1999; 140(11):4939-4947.

14. Tena-Sempere M, Pinilla L, González LC, Diéguez C, Casanueva FF, Aguilar E. Leptin inhibits testosterone secretion from adult rat testis in vitro. J Endocrinol. 1999;161(2):211-218.

15. National Center for Health Statistics. (1988-1991). National Health and Nutrition Examination Survey (NHANES) III. 1988-1991. https://wwwn.cdc .gov/nchs/nhanes/nhanes3/Default.aspx (accessed February 22, 2020).

16. Ahluwalia N, Dwyer J, Terry A, Moshfegh A, Johnson C. Update on NHANES dietary data: Focus on collection, release, analytical considerations, and uses to inform public policy. Adv Nutr. 2016;7(1): 121-134.

17. Alberti KG, Zimmet P, Shaw J; IDF Epidemiology Task Force Consensus Group. The metabolic syndrome-a new worldwide definition. Lancet. 2005;366(9491):1059-1062.

18. Janssen I, Katzmarzyk PT, Ross R. Waist circumference and not body mass index explains obesity-related health risk. Am J Clin Nutr. 2004; 79(3):379-384.

19. Zhao J, Leung JY, Lin SL, Schooling CM. Cigarette smoking and testosterone in men and women: A systematic review and meta-analysis of observational studies. Prev Med. 2016;85:1-10.

20. Mulhall JP, Trost LW, Brannigan RE, et al. Evaluation and management of testosterone deficiency: AUA Guideline. J Urol. 2018;200(2) 423-432.

21. Vermeulen A, Verdonck L, Kaufman JM. A critical evaluation of simple methods for the estimation of free testosterone in serum. J Clin Endocrinol Metab. 1999;84(10):3666-3672.

22. Rinaldi S, Geay A, Déchaud H, et al. Validity of free testosterone and free estradiol determinations in serum samples from postmenopausal women by theoretical calculations. Cancer Epidemiol Biomarkers Prev. 2002 11(10 Pt 1):1065-1071.

23. Wulaningsih W, Holmberg L, Ng T, Rohrmann S, Van Hemelrijck M. Serum leptin, C-reactive protein, and cancer mortality in the NHANES III. Cancer Med. 2016;5(1):120-128.

24. Odle AK, Akhter N, Syed MM, et al. Leptin regulation of gonadotrope gonadotropin-releasing hormone receptors as a metabolic checkpoint 
and gateway to reproductive competence. Front Endocrinol (Lausanne). 2018;8:367.

25. Goulis DG, Tarlatzis BC. Metabolic syndrome and reproduction: I. testicular function. Gynecol Endocrinol. 2008;24(1):33-39.

26. Simon D, Preziosi $P$, Barrett-Connor $E$, et al. Interrelation between plasma testosterone and plasma insulin in healthy adult men: The Telecom Study. Diabetologia. 1992;35(2):173-177.

27. Haffner SM, Karhapää $P$, Mykkänen L, Laakso M. Insulin resistance, body fat distribution, and sex hormones in men. Diabetes. 1994;43(2): 212-219.

28. Behre HM, Simoni M, Nieschlag E. Strong association between serum levels of leptin and testosterone in men. Clin Endocrinol (Oxf). 1997;47(2): 237-240.

29. Mauras $N$, Hayes $V$, Welch $S$, et al. Testosterone deficiency in young men: Marked alterations in whole body protein kinetics, strength, and adiposity. J Clin Endocrinol Metab. 1998;83(6):1886-1892.

30. Landry DA, Sormany F, Haché J, Roumaud P, Martin L. Steroidogenic genes expressions are repressed by high levels of leptin and the JAK/STAT signaling pathway in MA-10 Leydig cells. Mol Cell Biochem. 2017;433(1-2):79-95.

31. Khodamoradi K, Parmar M, Khosravizadeh Z, Kuchakulla M, Manoharan M, Arora $\mathrm{H}$. The role of leptin and obesity on male infertility. Curr Opin Urol. 2020;30(3):334-339.

32. Baltaci AK, Mogulkoc R, Ozturk A. Testosterone and zinc supplementation in castrated rats: Effects on plasma leptin levels and relation with $\mathrm{LH}, \mathrm{FSH}$ and testosterone. Life Sci. 2006;78(7):746-752.

33. Kacker R, Traish AM, Morgentaler A. Estrogens in men: Clinical implications for sexual function and the treatment of testosterone deficiency. J Sex Med. 2012;9(6):1681-1696.

34. Dhindsa S, Batra M, Kuhadiya N, Dandona P. Oestradiol concentrations are not elevated in obesity-associated hypogonadotrophic hypogonadism. Clin Endocrinol (Oxf). 2014;80(3):464.

35. Isidori AM, Caprio M, Strollo F, et al. Leptin and androgens in male obesity: Evidence for leptin contribution to reduced androgen levels. J Clin Endocrinol Metab. 1999;84(10):3673-3680.

36. Isidori AM, Strollo F, Morè $M$, et al. Leptin and aging: Correlation with endocrine changes in male and female healthy adult populations of different body weights. J Clin Endocrinol Metab. 2000;85(5):1954-1962.
37. Ostlund RE, Yang JW, Klein S, Gingerich R. 1996 Relation between plasma leptin concentration and body fat, gender, diet, age, and metabolic covariates. J Clin Endocrinol Metab. 81:3909-3913.

38. Seftel A. Male hypogonadism. Part II: Etiology, pathophysiology, and diagnosis. Int J Impot Res. 2006;18(3):223-228.

Cite this article as: Fernandes Negris Lima T, Nackeeran S, Rakitina E, Fernandes Negris Lima G, Arora H, Kargi AY, Ramasamy R (2020) Association of leptin with total and free testosterone: results from the National Health and Nutrition Examination Surveys, Androgens: Clinical Research and Therapeutics 1.1, 94-100, DOI: 10.1089/ andro.2020.0007.

$\begin{aligned} & \text { Abbreviations Used } \\ & \mathrm{BMI}=\text { body mass index } \\ & \mathrm{CDC}=\text { Center for Disease Control and Prevention } \\ & \mathrm{CFT}=\text { calculated free testosterone } \\ & \mathrm{Cl}=\text { confidence interval } \\ & \mathrm{E}_{2}=\text { estradiol } \\ & \mathrm{FE}=\text { free estradiol } \\ & \mathrm{FT}=\text { free testosterone } \\ & \mathrm{GnR}=\text { gonadotropin-releasing hormone } \\ & \mathrm{hCG}=\text { human chorionic gonadotropin } \\ & \mathrm{HPG}=\text { hypothalamic-pituitary-gonadal } \\ & \mathrm{NHANES}=\text { National Health and Nutrition Examination Survey } \\ & \mathrm{SE}=\text { standard error } \\ & \mathrm{SHBG}=\text { sex hormone binding globulin } \\ & \mathrm{T}=\text { testosterone } \\ & \mathrm{TD}=\text { testosterone deficiency }\end{aligned}$

Publish in Androgens: Clinical Research and Therapeutics

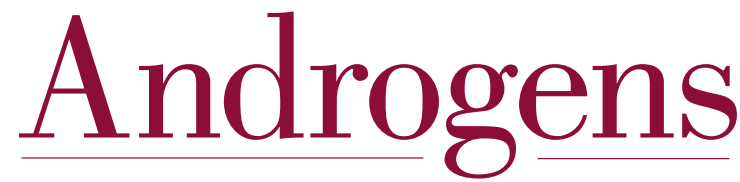

Clinical Research and Therapeutics

liebertpub.com/andro 